\title{
Analysis on problems and countermeasures existing in the teaching management of credit grade point system in universities
}

\author{
Baohua Cui \\ Economic Management Department, Jilin Agricultural University, \\ Changchun, China \\ Email: cbhjlau@yeah.net
}

Keywords: credit system; teaching management; problems; countermeasures

\begin{abstract}
The credit system is a teaching management system that takes credit as basic units to evaluate students' learning. This paper expounds the main content of the credit system teaching management and analyzes the problems in the teaching management of credit grade point system and puts forward some measures to improve the effectiveness of the credit system teaching management.
\end{abstract}

\section{Introduction}

The reform and development of the 21st century higher education has become a hot topic of people from all walks of life. It requires the higher education to reform constantly to adapt to its development because of the trend of internationalization of higher education, the change of social demand for education products, the management mechanism of higher education itself and social development, and the incompatibility between social demand and the supply of innovative talents and high-quality talents. The practicing of credit system in domestic and foreign countries shows that the credit system is the teaching management system which is conducive to innovation talents cultivation. Taking the implementation of the credit system as the breakthrough point, we can effectively promote the reform of the current teaching management system. This paper discusses universities' teaching management in our country based on credit system and puts forward explorative thinking on problems of the current credit system reform and the key points of the reform.

\section{The significance of credit grade point system in universities}

The credit system is a teaching management system that takes the level of students' education as calculating unit based on the premise of course selecting system and takes the minimum necessary credit as graduation standard. The socialist market economy requires higher education to establish interdisciplinary talents training mode, adjust specialties, broaden the professional breadth, and promote students' employment ${ }^{[1]}$. The realization of these requirements needs to transform from the old stiff school year teaching management system to more flexible credit system. Its significance lies in that attaching same weight to different courses of same credits in the evaluation system can better adapt to the request of the deep reform of higher education. Under the premise of the fundamentality and unity of national compulsory courses, the credit system checks and motivate students effectively choose the courses and class periods based on their intellectual level difference, the individual difference, the difference of interests and hobbies and the difference of employment guidance in the future. It can both reduce the heavy academic load of students and is beneficial to enrich the students' knowledge structure, cultivate their various skills, and develop fully, actively and harmoniously.

\section{The main content of the teaching management based on credit grade point system}

Teaching management is the process of comprehensive management of teaching process which takes the teaching goal as the guidance and follows the teaching laws and characteristics. Teaching 
plan can reasonably and flexibly arrange the curriculum according to the characteristics of the profession and guide students to study in school. Students can choose different elective courses according to their own hobby on the basis of finishing the compulsory courses. Syllabus makes students are clear about the course credits, hours, contents and study conditions and also make them understand with a glance in the process of course selection. The unit of credit system is school. Students choose their own course based on their overall teaching curriculum and query and print out their own schedule through the login of the school's teaching network. In the teaching management of credit system, students can obtain corresponding credits as long as their grades are qualified and the educational system is also flexible ${ }^{[2]}$. Students can choose a minor major in other disciplines and apply for dual degree. The credit system can effectively manage student status of students. Tutorial system is matching with the credit system and tutors regularly guide the student to study and also guide the student's professional direction and study plan according to the talent training scheme. The teaching quality management of credit system includes course teaching quality evaluation, students' information feedback, the teaching quality supervision, etc.

\section{Difficulties in implementing credit grade point system in universities}

\section{The quantity and quality of the course are obviously insufficient.}

The features of relatively single current course pattern and insufficient course quantity and quality are as follows: the first one is to think highly of the construction of the required courses and neglect the development of the elective course. The second is the course construction lacks of openness and innovation. Theory instilling class is given priority in curriculum setting and the practice class synchronized with theory is insufficient and the practice class lacks a better assessment standard. The third one is too specialized curriculum and too narrow course coverage. In the university teaching mode of academic year credit system, the disciplinary boundary is too strict and the professional division is too detailed. The professional characteristic of curriculum setting leads to narrow course coverage and few people can adapt to it ${ }^{[3]}$.

\section{Teacher resources are difficult to meet demand.}

Insufficient quantity and quality of teacher resources seriously restricts the implementation of the credit system in colleges and universities and also makes it difficult to achieve that students choose their courses and teachers freely with the credit system. Teachers themselves lack broad professional knowledge and high cultural accomplishment and their single knowledge structure and arrow marketability make them disable to open a new lesson. Teachers' teaching concept needs to be updated. Teachers are constrained by their own professional in the teaching process and take the achievement of the teaching objectives as the main task. They adopt simple instilling teaching methods and single form in the classroom teaching.

\section{Lagging teaching management and teaching evaluation.}

The lagging teaching management in the current process of implementing credit system in colleges and universities lies in the following three aspects: the first one is the teaching management system is not sound. The complete credit system is the target management mode, which emphasizes the objective evaluation and reduces the attention to the process of teaching. There are a lot of changing and withdrawing in the chosen course existing while students break the boundary of professional course and grade, which requires the corresponding regulations and strong method of informatization to guarantee ${ }^{[4]}$. The second one is the students management model needs to be changed. The complete credit system weakens the administrative management mode and the freedom and flexibility of class size are increased under the influence of the elective system. The third is teaching evaluation ways need to be changed. Under the complete credit system, the teachers' teaching is flexible and teachers have the right to adjust their teaching content and teaching form in accordance with the teaching schedule.

\section{It is hard to realize teaching quality monitoring.}

While the credit system is emphasizing students' individuality development, proper constraints of students' life are insufficient which inevitably brings difficulty to quality monitoring. The Open flexible talent training scheme leads to the students' imperfection even with blindness of course 
selection and they will choose their favorite courses without estimating the characteristics of the discipline. The autonomy of course selection results in students' study "transgender" which means that students will choose the courses of which the credit is easy to obtain. It is hard to use the system to avoid the two options. At the same time, because the credit system emphasizes the results management, process management is inevitably ignored which increases the difficulty of the teaching quality monitoring.

\section{Countermeasures of the implementation of teaching management model of the credit grade point system}

\section{Transform the management concept of teaching workers.}

Transforming the management concept of teaching workers is the premise of the smooth implementation of "credit grade point system". Specifically, the first thing is to improve "tutorial system". In order to improve the system of "tutorial system", the teacher's main job responsibilities must be combined with the characteristics of students, guide students to establish professional ideas, help students establish scientific knowledge structure, build a reasonable elective system, and recommend them taking the corresponding course based on the characteristics of professional and social demand. Secondly, establish the concept of "class" anew and break through the traditional concept of stable administrative class and establish the concept of "program". Thirdly, correctly understand the importance of the exam grade point. Under the condition of "credit grade point system", students can graduate and get the degree only by acquiring the regulation of credit and achieving the specified grade point of the training scheme. The higher grades they get, the higher grade point they can obtain.

\section{Expand elective course resources and build a reasonable system of elective courses.}

In order to achieve the teaching goal under the "Credit grade point system" mode, we should guarantee elective course resources based on the system, encourage teachers to combine their own situation and student demand, combine the present situation of professional development and research front, and constantly develop new courses resources. Add scientific and technological innovation training credits and adopt them into the talent training scheme by borrowing "college students' innovation training plans". While expanding the curriculum resources, we should make full use of intercollegiate resources and enrich the elective courses resource by using online courses, online teaching and other forms to provide more learning content to students ${ }^{[5]}$.

\section{Improve faculty resources and management level.}

Build a high-quality teaching staff and a stable teaching management team is the premise and foundation of implementation of "credit grade point system". The ascension of the teachers troop quality relies on the school relevant policies and measures to a large extent except for the teachers' efforts. Therefore, School should perfect the system of evaluation of teachers from the system level and encourage teachers conduct further study or training to enhance their professional quality and professional level and continuously explore new curriculum resources which can meet the needs of students. At the same time, take measures to stabilize the teaching management team. Conduct the regular training on required skills under the "credit grade point system" teaching management mode on this basis and enhance the quality of managers to better adapt to the requirement of "credit grade point system" teaching management mode.

\section{Conclusion}

In a word, the implementation of credit system is the inevitable trend of higher education reform in domestic universities which has made great achievements and cultivated a large number of personalized and diversified talents. However, the teaching management under the credit system involves many factors which still need to be explored and improved in practice. Therefore, we should raise awareness based on the construction of "human-oriented harmonious campus" and set in from reality and follow the rules of education teaching. Transform teaching management concept and give full play to teachers' and students' ownership. Absorb the advanced experience of domestic 
and foreign countries about credit system management and grasp the opportunity. Continuous innovation can ensure the effective implementation of the credit system and cultivate creative and comprehensive talents.

\section{References}

[1] Yang Zhiyun. Exploration and practice of credit system reform in colleges and universities. [J] Heilongjiang Researches on Higher Education, 2005,(11).

[2] Li Meijie. Treat elective courses from the angle of the discipline construction. [J]. Educator, 2011(5).

[3] Li Xiaojie. Research on the construction of credit system in colleges and universities conforms to China's national conditions. [D]. Dalian University Of Technology, 2009.

[4] Liu Minghong. Explore the ways to strengthen the scientification and effectiveness of the teaching management in colleges and universities. [ J ] . Journel of Jiangsu University of Science and Technology (Social Science Edition), 2006, (3).

[5] Li Guihong. Research on the current situation, problems and countermeasures of the credit system in China's colleges and universities. [D]. Hebei: Hebei Normal University, 2010. 